\title{
Tips on Constructing Inclusive and Equitable Guided Microlearning Inquiry Questions to Clarify Topics in General Biology
}

Robert M. Kao

Assistant Professor in Biology, Heritage University, Toppenish, WA, 98948

\section{Kao r@heritage.edu}

Author declares no conflict of interest.

\begin{abstract}
Some of the key features of inclusive and equitable teaching approaches encourage prompt feedback, student cooperation in communities of learning, active learning, and promotes diverse ways of knowing in the classroom. In my article, I present step-bystep tips to help instructors create guided microlearning inquiry questions within an inclusive and equitable general biology classroom setting. Microlearning is a special approach that helps students complete a specific task linked to a specific learning objective that would be completed in a short time window around five minutes. The step-by-step tips presented in my article helps instructors to develop questions aligned to specific learning objective to help clarify unclear or confusing topics in general biology using the Kahoot e-Learning platform. This guided microlearning inquiry toolkit provides a blueprint for helping instructors to infuse student-centered approaches to help clarify difficult concepts in general biology and further develop avenues refine students' critical thinking and experimental design in biology research.
\end{abstract}




\section{Manuscript Text}

\section{Introduction}

Inclusive and equitable teaching approaches encourage prompt feedback, student cooperation in communities of learning, active learning, and promotes diverse ways of knowing in the classroom (Chickering 1987). One of the approaches to help students learn is using an approach called microlearning: a special approach that helps students complete a specific task linked to a specific learning objective that would be completed in a short time window around five minutes (Eades 2014). Recently, one microlearning approach called BRYT has been used in the context of library learning (An 2018). Through reflective journaling over the past three years, I have noted down undergraduate students' general biology concepts that are unclear or confusing. Aligned with Vision and Change (2011), these general biology concepts are similar general biology misconceptions reported by colleagues in the undergraduate biology research community. To help undergraduates engage student to clarify unclear and difficult topics and concepts in general biology (Halim 2018), I have developed a guided microlearning inquiry toolkit that instructors can adapt and implement into their classrooms.

Over the past year, this guided microlearning inquiry toolkit has been implemented into the adaptable SOAR framework (Kao 2018). The Helping Students SOAR framework is defined as the following: Spiral curricula and process of inquiry (spiralquiry); Observations from experiments to evaluation of data; Affective learning in active learning settings; and Research year-round across the undergraduate curricula (Kao 2018 ). The flexible SOAR framework is also aligned with recent inclusive and equitable approaches in evidence-based life science education literature (Dewsbury and Brame 2019, Schinske 2016, Tanner 2007, Tanner 2013). For example, I structured weekly quizzes and mini-portfolios (quizfolios) to not only allow all undergraduates with biology concepts, but also reflect on the lived experiences and stories of Drs. Erich Jarvis and Roberto Ramirez. In summary, these culturally-responsive teaching and mentoring approaches provide inclusive and equitable learning environments for all undergraduates.

Here, I present step-by-step tips to help instructors create guided microlearning inquiry questions.

\section{Step-by-step Tips to Construct Guided Microlearning Questions}

The following six steps were used to create guided microlearning inquiry questions:

1. Instructor collected students' responses from previous classes and/or quizfolio assignments to identify terms/concepts that were unclear or confusing. For example, one of the concepts that was unclear during the general biology course was mechanistic action of receptor-mediated endocytosis. 
2. After collecting student' terms/concepts that were unclear or confusing, a learning objective for the microlearning was then constructed by the instructor. For example, one learning objective for microlearning is the following: Clarify the molecular mechanism of receptor-mediated endocytosis.

3. After creating receptor-mediated endocytosis learning objective for microlearning, a question was made using the e-Learning platform called Kahoot. An example question was made using Kahoot:

Which of the following statement(s) would likely inhibit receptor mediated endocytosis function?
A. Decreased function of ribosomes
B. Loss of function mutation in active site of receptor
C. Decreased function of splicesomes
D. Gain of function in enzyme that inhibits receptor function

4. Instructor then implemented series of questions in guided micro-learning inquiry using Kahoot platform within culturally-responsive and inclusive learning classroom environment that included additional exam review questions.

5. Instructor clarified each micro-learning question during inclusive and equitable inclass discussions. A podcast recording and notes were provided to all students. For example, after students worked in teams or individually to answer the Kahoot microlearning question, the instructor then guided the logic reasoning behind why either loss-of-function mutation in active site of receptor and gain-of-function in enzyme that inhibits receptor function are two mechanisms that block or inhibit receptor mediated endocytosis function. The definition of receptor mediate endocytosis will also be reviewed as well.

6. A specific question designed to test students' learning outcome of how to perform analysis and evaluation and experimental design from exam question was used to assess student performance in the midterm or final exam. BioCore Guide was used to help develop the semester long general biology course (Brownell 2014). Table 2 illustrates a rubric guide used to assess student learning outcomes.

\section{Summary}

The construction of guided microlearning inquiry questions help students to develop self-explanations and logic reasoning in biology research experimental design and critical thinking skills. In addition, these microlearning tools may be adaptable into existing inclusive and equitable active learning in-class teaching settings (Dewsbury and 
Brame 2019, Tanner 2007, Tanner 2013), such as figure facts (Round and Campbell 2013). Furthermore, guided microlearning questions may also be incorporated into Quizlet and other e-learning platforms as well. Finally, the instructor may adjust the guided microlearning inquiry questions depending on what students identify are most difficult or unclear topics in general biology, as well as other upper level biology courses, such as developmental genetics and molecular cell biology.

\section{Tables:}

Table 1: Instructor Guide to Create Guided Microlearning Questions (C $C^{3}$ IDA Tips)

Table 2: Rubric to Assess Student Learning Outcomes

\section{Acknowledgements:}

My guided microlearning inquiry is dedicated to the life and spirit of Anonymous, as well as fellow faculty colleagues and all undergraduate scholars of General Biology II since Spring of 2017 in my life-long learning journey. In addition, I want to thank anonymous reviewers during the peer-review process for their helpful comments and suggestions.

\section{References:}

2011. Vision and Change in Undergraduate Biology Education: A Call to Action. 1-100. An, Angie; Quail, Stephanie. 2018. "Building BRYT: A Case Study in Developing an Online Toolkit to Promote Business Information Literacy in Higher Education." Journal of Library \& Information Services in Distance Learning 12 (3-4):71-89.

Brownell, Sara E., Freeman, Scott, Wenderoth, Mary Pat, and Crow, Alison J. 2014. "BioCore Guide: A Tool for Interpreting the Core Concepts of Vision and Change for Biology Majors." CBE - Life Sciences Education 13. doi: DOI: 10.1187/cbe.13-12-0233.

Chickering, Arthur W.; Gamson, Zelda F. 1987. "Seven Principles for Good Practice in Undergraduate Education." AAHE Bulletin:3-7.

Dewsbury, B., and C. J. Brame. 2019. "Inclusive Teaching." CBE Life Sci Educ 18 (2):fe2. doi: 10.1187/cbe.19-01-0021.

Eades, John. 2014. "Why Microlearning is Huge and How to Be a Part of It." accessed March 14, 2019. https://elearningindustry.com/why-microlearning-is-huge.

Halim, Audrey S.; Finkenstaedt-Quinn, Solaire A.; Olsen, Laura J.; Ruggles Gere, Anne; and Shultz, Ginger V. 2018. "Identifying and Remediating Student Misconceptions in Introductory Biology via Writing-to-Learn Assignments and Peer Review." CBE Life Sci Educ 17 (28):1-12.

Kao, Robert M. 2018 "Helping Students SOAR: Quizfolio Tips to Engauge First Generation Underrepresented Minority Undergraduates in Scientific Inquiry." The American Biology Teacher 80 (3):228-234.

Round, J. E., and A. M. Campbell. 2013. "Figure facts: encouraging undergraduates to take a data-centered approach to reading primary literature." CBE Life Sci Educ 12 (1):39-46. doi: 10.1187/cbe.11-07-0057.

Schinske, J. N., H. Perkins, A. Snyder, and M. Wyer. 2016. "Scientist Spotlight Homework Assignments Shift Students' Stereotypes of Scientists and Enhance Science Identity in a 
Diverse Introductory Science Class." CBE Life Sci Educ 15 (3). doi: 10.1187/cbe.16-010002.

Tanner, Kimberly and Allen, Deborah. 2007. "Cultural Competence in the College Biology Classroom." CBE Life Sciences Education 6:251-258.

Tanner, Kimberly D. 2013. "Structure Matters: Twenty-One Teaching Strategies to Promote Student Engagement and Cultivate Classroom Equity." CBE Life Sciences Education $12: 322-331$. 
Table 1: Instructor Guide to Create Guided Microlearning Questions (C ${ }^{3}$ IDA Tips)

\begin{tabular}{|c|c|}
\hline Step & Instructor Notes Guide \\
\hline $\begin{array}{l}\text { 1. Collect } \\
\text { students' } \\
\text { topics/concepts } \\
\text { that are } \\
\text { unclear or } \\
\text { confusing. }\end{array}$ & $\begin{array}{l}\text { Topics that are unclear or confusing can be done via } \\
\text { previously assigned homework, quiz-mini portfolios } \\
\text { (quizfolios), or one-minute paper responses. Instructors can } \\
\text { preview ahead of time before upcoming class, or can } \\
\text { explicitly ask students to reflect and write down } \\
\text { terms/concepts that are unclear or confusing at the beginning } \\
\text { of class. }\end{array}$ \\
\hline $\begin{array}{l}\text { 2. Create one } \\
\text { learning } \\
\text { objective for } \\
\text { microlearning. }\end{array}$ & $\begin{array}{l}\text { Pick one of the topics or biology concepts students have } \\
\text { mentioned and write one learning objective to be covered } \\
\text { using microlearning. }\end{array}$ \\
\hline $\begin{array}{l}\text { 3. Create one } \\
\text { specific } \\
\text { question } \\
\text { aligned to } \\
\text { learning } \\
\text { objective. }\end{array}$ & $\begin{array}{l}\text { Take the learning objective from step two and develop a } \\
\text { question that is aligned to the specific learning objective. }\end{array}$ \\
\hline $\begin{array}{l}\text { 4. Implement } \\
\text { question onto } \\
\text { Kahoot or } \\
\text { another online } \\
\text { gamification } \\
\text { platform. }\end{array}$ & $\begin{array}{l}\text { Place the question into Kahoot or another online gamification } \\
\text { platform and have students work in groups during in-class } \\
\text { discussion. }\end{array}$ \\
\hline $\begin{array}{l}\text { 5. Debrief } \\
\text { microlearning } \\
\text { question during } \\
\text { in-class } \\
\text { discussions. }\end{array}$ & $\begin{array}{l}\text { Go over the question and explain the best response(s) to the } \\
\text { question. Clarify term or concept for students. In addition, } \\
\text { link these topics to important themes in biology. }\end{array}$ \\
\hline $\begin{array}{l}\text { 6. Assess } \\
\text { students' } \\
\text { performance in } \\
\text { analyzing and } \\
\text { evaluating data } \\
\text { and } \\
\text { experimental } \\
\text { design. }\end{array}$ & $\begin{array}{l}\text { Using rubric in Table 2, instructors can create multi-part } \\
\text { questions that test general biology concepts that are linked to } \\
\text { Vision and Change (2011) and BioCore Guide (Brownell, et } \\
\text { al. 2014). These questions test students' performance goals } \\
\text { in how to analyze and evaluate data and experimental } \\
\text { design. }\end{array}$ \\
\hline
\end{tabular}


Table 2: Rubric to Assess Student Learning Outcomes

\begin{tabular}{|c|c|c|c|c|}
\hline $\begin{array}{l}\text { Learning } \\
\text { Outcome }\end{array}$ & $\begin{array}{l}\text { Initial } \\
1.0\end{array}$ & $\begin{array}{l}\text { Emerging } \\
2.0\end{array}$ & $\begin{array}{l}\text { Developing } \\
3.0\end{array}$ & $\begin{array}{l}\text { Outstanding } \\
4.0\end{array}$ \\
\hline $\begin{array}{l}\text { Analyze data } \\
\text { from primary } \\
\text { research } \\
\text { articles. }\end{array}$ & $\begin{array}{l}\text { Ill-defined } \\
\text { ability to take } \\
\text { observations } \\
\text { and interpret } \\
\text { data. }\end{array}$ & $\begin{array}{l}\text { Some ability to } \\
\text { observe } \\
\text { changes in } \\
\text { data over time } \\
\text { and space, but } \\
\text { data } \\
\text { interpretation is } \\
\text { lacking. }\end{array}$ & $\begin{array}{l}\text { Developing } \\
\text { ability to } \\
\text { observe } \\
\text { changes in } \\
\text { data over time } \\
\text { and space, } \\
\text { with some data } \\
\text { interpretation } \\
\text { of results. }\end{array}$ & $\begin{array}{l}\text { Outstanding } \\
\text { ability to both } \\
\text { observe } \\
\text { changes of } \\
\text { data over time } \\
\text { and space, } \\
\text { with excellent } \\
\text { ability to } \\
\text { formulate data } \\
\text { interpretation } \\
\text { of results. }\end{array}$ \\
\hline $\begin{array}{l}\text { Evaluate data } \\
\text { from primary } \\
\text { research } \\
\text { articles. }\end{array}$ & $\begin{array}{l}\text { Ill-defined } \\
\text { ability to take } \\
\text { results of data } \\
\text { and draw } \\
\text { conclusion. }\end{array}$ & $\begin{array}{l}\text { Some ability to } \\
\text { take results } \\
\text { and attempt to } \\
\text { develop } \\
\text { conclusion } \\
\text { based upon } \\
\text { data. }\end{array}$ & $\begin{array}{l}\text { Developing } \\
\text { ability to take } \\
\text { results and } \\
\text { some evidence } \\
\text { to draw } \\
\text { conclusion } \\
\text { based upon } \\
\text { data. }\end{array}$ & $\begin{array}{l}\text { Outstanding } \\
\text { ability to take } \\
\text { results and } \\
\text { formulate } \\
\text { specific } \\
\text { conclusion of } \\
\text { results based } \\
\text { upon data at } \\
\text { hand. }\end{array}$ \\
\hline $\begin{array}{l}\text { Formulate an } \\
\text { experimental } \\
\text { design to } \\
\text { address } \\
\text { specific } \\
\text { testable } \\
\text { hypothesis. }\end{array}$ & $\begin{array}{l}\text { Ill-defined } \\
\text { ability to } \\
\text { include control } \\
\text { and } \\
\text { experimental } \\
\text { groups. Lacks } \\
\text { focus in } \\
\text { addressing } \\
\text { specific } \\
\text { research } \\
\text { question } \\
\text { and/or testable } \\
\text { hypothesis. }\end{array}$ & $\begin{array}{l}\text { Some ability to } \\
\text { formulate } \\
\text { appropriate } \\
\text { control and } \\
\text { experimental } \\
\text { group, but } \\
\text { outcomes to } \\
\text { measure are } \\
\text { not defined. } \\
\text { Mix up of } \\
\text { control and } \\
\text { experimental } \\
\text { group. } \\
\text { Experimental } \\
\text { design does } \\
\text { not fully } \\
\text { address } \\
\text { research } \\
\text { question } \\
\text { and/or testable } \\
\text { hypothesis. }\end{array}$ & $\begin{array}{l}\text { Good ability to } \\
\text { formulate both } \\
\text { control and } \\
\text { experimental } \\
\text { group to test } \\
\text { research } \\
\text { question } \\
\text { and/or testable } \\
\text { hypothesis. } \\
\text { Measurable } \\
\text { outcomes not } \\
\text { well defined. }\end{array}$ & $\begin{array}{l}\text { Outstanding } \\
\text { ability to } \\
\text { formulate } \\
\text { control and } \\
\text { experimental } \\
\text { group to } \\
\text { resolve } \\
\text { research } \\
\text { question and/or } \\
\text { test specific } \\
\text { hypothesis at } \\
\text { hand. } \\
\text { Outcomes to } \\
\text { measure are } \\
\text { specific to } \\
\text { research } \\
\text { question and/or } \\
\text { testable } \\
\text { hypothesis. }\end{array}$ \\
\hline
\end{tabular}

